\title{
Editor's Note: Fall 2020 Issue
}

\author{
Joshua Kunnath \\ JSARD Editor
}

\begin{abstract}
As editor of the Journal of School Administration Research and Development (JSARD), I'm proud to present our Fall Issue, which is our third issue of 2020. This Fall Issue is our penultimate issue of the year-only to be followed by part two of our fifth anniversary special issue.

As alluded to above, this year is a special one for JSARD, as we celebrate our fifth anniversary. Since our first issue in the summer of 2016, our mission has been to publish and disseminate relevant, high-quality literature in educational leadership in order to empower researchers, practitioners, and policymakers to improve K-12 schools. And I think this Fall Issue well aligns to that mission.

In the literature that follows, you will find four research articles and one essay that address the topics of curriculum, mental health services, and special educator evaluation-all in the context of school leadership. The authors are researchers and practitioners, coming from settings that include the university, the high school classroom, and the hospital.

I hope that this issue provides you with a new perspective, idea, or insight that you can apply to your role in education-whatever the capacity may be. Further, I invite you share this literature with a colleague, leader, or friend to effectively partner in our work to support the development and dissemination of research and scholarship in the area of K12 school administration and leadership.
\end{abstract}

Sincerely,

Joshua Kunnath, EdD 